\title{
ECONOMIC VERSUS POLITICAL LIBERALISATION IN ASEAN: PUBLIC OPINION AMONG UNIVERSITY STUDENTS IN FOUR MEMBER COUNTRIES
}

\author{
Guido Benny* \\ School of Liberal Arts and Social Sciences, \\ Taylor's University, No. 1 Jalan Taylor's, \\ 47500 Subang Jaya, Selangor, Malaysia \\ E-mail: guidobenny@gmail.com
}

Sity Daud D* $^{*}$

History, Politics and Security Research Centre, Faculty of Social Sciences and Humanities, Universiti Kebangsaan Malaysia, 43600 UKM Bangi, Selangor, Malaysia

E-mail: sitydaud@ukm.edu.my

Ravichandran Moorthy***

History, Politics and Security Research Centre, Faculty of Social Sciences and Humanities, Universiti Kebangsaan Malaysia,

43600 UKM Bangi, Selangor, Malaysia

E-mail: drravi5774@gmail.com

Published online: 15 January 2018

To cite this article: Benny, G., Daud, S. and Moorthy, R. 2018. Economic versus political liberalisation in ASEAN: Public opinion among university students in four member countries. International Journal of Asia Pacific Studies 14 (1): 227-249, https://doi. org/10.21315/ijaps2018.14.1.9

To link to this article: https://doi.org/10.21315/ijaps2018.14.1.9

\begin{abstract}
As a regionalism initiative, establishment of the ASEAN Community needs plausible level of public awareness, good public perception and strong public support from the public for its legitimacy. The current paper discusses the opinion among the public pertaining to regional economic integration under the ASEAN Economic Community initiative in comparison to political-security cooperation under the ASEAN Political Security Community in 2015 among educated public in four ASEAN countries, namely Malaysia, Indonesia, Thailand and Vietnam. The study aims to solicit and


compare the current situation of public opinion of these two kinds of liberalisation in ASEAN within the context of awareness, perception, and support. The research objectives were achieved by means of statistical measures and analyses on the opinion among 1,471 Gen Y respondents in these four ASEAN countries gathered from a public opinion survey in 2015. The study reveals interesting findings. Firstly, it found that the extent of awareness of both APSC and AEC is still weak resulting in weak extent of perceived relevancy and benefits as well as weak support for APSC and moderate-level support for AEC. Secondly, by comparing the opinion on APSC to AEC, the study found that awareness, perception and support for economic integration in ASEAN were in fact higher than political security cooperation. Finally, some implications of these issues are discussed.

Keywords: ASEAN Community, regionalism, economic integration, political cooperation, public opinion

\section{INTRODUCTION}

Regional integration, either induced by people's economic regionalisation and/ or state regionalism initiatives, are perhaps the most notable and consequential feature of the international economic and political landscape to take shape in many part of the world since the end of the Cold War (Benny et al. 2015a). As a worldwide phenomenon of increased interaction between actors (state and non-state) in economic, security, political, social and cultural spheres, regional integration has emerged in different stages in various parts of the world, with its most developed form in the European Union (hereafter, EU).

The Association of Southeast Asian Nations (hereafter, ASEAN) has been regarded as one of the most successful regional integration initiatives among the developing countries (Benny, Tham and Ramli 2015). Since its inception in 1967, ASEAN has been considered as successful in maintaining political stability and security that has in part contributed towards the rapid economic growth of its five founding members during 1960s-1990s. Although its initial reasons for establishment was mainly political - to secure the region's peace, stability and development - its aims include the promotion of regional economic, social and cultural cooperation among the five founding countries of Southeast Asia (Tan 2004: 935).

The Asian Financial Crisis (AFC) in 1997 and increasing competition for investment flows from a rising China and India had caused ASEAN leaders to realign strategies for ASEAN economic integration. Accordingly, they adopted the ASEAN Vision 2020 in December 1997 that describe the 
aspiration of an ASEAN Community as a concert of Southeast Asian nations, outward looking, living in peace, stability and prosperity, bonded together in partnership in dynamic development and in a community of caring societies to be achieved by the end of 2020. Subsequently, a founding document of the ASEAN Community - the Declaration of Bali Concord II - in 2003 declare the three pillars consisting of the ASEAN Political Security Community (hereafter, APSC), ASEAN Economic Community (AEC), and ASEAN Socio-Cultural Community (hereafter, ASCC) as its new goal in regional integration. Later, the 12th ASEAN Summit accelerated the deadline of the ASEAN Community establishment to 2015.

The Bali Concord II describes that "APSC is envisaged to bring the ASEAN's political and security cooperation to a higher plane to ensure that countries in the region live at peace with one another and with the world at large in a just, democratic and harmonious environment, of which members shall rely exclusively on peaceful processes in the settlement of intra-regional differences and regard their security as fundamentally linked to one another and bound by geographic location, common vision and objectives, while keep maintaining the respects for the ASEAN Way enshrined in the Treaty of Amity and Cooperation (TAC)." The Declaration also defined the AEC as "the realisation of the end-goal of economic integration as outlined in the ASEAN Vision 2020, to create a stable, prosperous and highly competitive ASEAN economic region in which there is a free flow of goods, services, investment and a freer flow of capital, equitable economic development and reduced poverty and socio-economic disparities in year 2020."

In 2007, the lofty goals of the APSC and AEC were translated into action when the ASEAN leaders issued the Declaration on the APSC Blueprint as well as the AEC Blueprint. The Blueprint is essentially a master plan formulated for guiding the achievement of an APSC and AEC by 2015. There is moderate progress on the economic integration and political cooperation among ASEAN members approaching the declaration of ASEAN Community establishment in 2015 (Abdullah and Benny 2013).

Critics however remain sceptical on ASEAN political and economic integration (Abdullah and Benny 2013). On political integration, some wellknown scholars - Acharya (2003), Caballero-Anthony (2008), and Chavez (2007) - argue that the development and process of ASEAN Community appeared to be elitist and state-centric. On ASEAN economic integration, some studies (Research Institute for ASEAN and East Asia, ERIA 2012; Asian Development Bank Institute, ADBI 2012) indicate that there has been some success in achieving some of the goals of the Blueprint, economic 
integration is still very much work in progress or the AEC is still essentially a community in the making, when measured against its stated goals. Moreover, despite a plethora of summits, meetings, plans and protocols designed both to strengthen economic integration in the region, the AEC is essentially a topdown initiative for establishing a single market and production base (Benny, Tham and Ramli 2015). The general public of member countries has never been involved in the building process of the ASEAN Community and the AEC (Benny and Abdullah 2011; Chavez 2007; Moorthy and Benny 2012a and 2012b). Thus, there is a huge gap between the states' elites and the public in terms of decision making and the formation of ASEAN Community.

The study strongly argues that establishing regional integration needs basic conceptualisation, understanding and support from the public of the region. Theories of regional integration have shown that opinions and participation among the public would determine the success of such efforts (Benny, Ramli and Tham 2014; Abdullah and Benny 2013; Benny and Abdullah 2011; Moorthy and Benny 2012a, 2012b, 2013; Collins 2008; Lindberg and Scheingold 1970; Hewstone 1986; Ortuoste 2008). So far, regional integration process in ASEAN lacks public involvement in its process (Abdullah and Benny 2013). Furthermore, there is also no comprehensive measurement on the support, opinions, or consensus of the public on the creation of the ASEAN Community. There is also a notable lack of studies that have attempted to capture the voices of the public on an ASEAN Community. This is not to mention the absence of studies that compares public knowledge, perception and supports for the formation of two of three basic pillars of the ASEAN Community, namely the APSC and AEC approaching the date of ASEAN Community effective establishment at the end of 2015.

Having said that, this research aims to compare opinion among the public in four countries surveyed (Indonesia, Malaysia, Thailand and Vietnam) pertaining to awareness, perception, and supports for APSC and AEC. More specifically, the research aims to: (1) assess the opinion-awareness, perception, and supports - of APSC and AEC in the four ASEAN countries; and (2) to compare the extent of the opinions towards the two ASEAN community pillars.

\section{LITERATURE REVIEW}

Assessment on scholarly literatures found no scholarly work comparing economic and political regionalism in the ASEAN Community context. Studies 
on the ASEAN are numerous, but conducted using the elite decision-making approach for assessing the establishment processes or the social, political and economic challenges of ASEAN (Acharya 2003; Benny, Tham and Ramli 2015; Hew 2007; Guerrero 2008) as well as the readiness of the business sector for the AEC (Abidin et al. 2012; Mugijayani and Kartika 2012). Review on the literature found that quite a few studies so far on public opinion on the establishment of ASEAN Community (e.g., Abdullah and Benny 2013; Benny 2014, 2015, 2016a, 2016b; Benny and Abdullah, 2011; Benny, Moorthy, Daud and Othman 2015a, 2015b; Benny, Ramli and Tham 2014; Benny, Tham and Ramli 2015; Moorthy and Benny 2012a, 2012b, 2013; Siraprapasiri and Thalang 2016; Thompson, Thianthai and Thuzar 2016), but only very limited number of studies discuss the opinion on AEC or APSC.

Literature Review found only two studies discussing public opinion on AEC. The first article, Public Opinion on the Formation of the ASEAN Economic Community: An Exploratory Study in Three ASEAN Countries, was written by Benny, Tham and Ramli (2015). It discusses the extent of public support, commitment, perceived benefits and aspiration among the public in Indonesia, Malaysia and Singapore in 2010 and found the differences in level of support, commitment and perceived benefits in three countries. However, this study is considered limited to the opinion among the public in three Malay archipelagic states five years before the effective implementation of AEC, so more current research is required to capture the present opinion among the public.

The most recent study on AEC was conducted by Benny (2015) who writes an article, Is the ASEAN Economic Community Relevant to Gen Y Professionals? A Comparative Study on Attitudes and Participation of Young Professionals in Malaysia, Indonesia, and Vietnam on ASEAN Economic Integration, on awareness and perception of relevancy of the AEC among the young professionals in Malaysia, Indonesia, and Vietnam countries during the final year of AEC establishment in 2015. He found that the awareness of the AEC among the Gen Y professionals was very weak, but they perceived the AEC as highly relevant for them individually and also for their country. The study goes further by analysing the influence of awareness on the perception and found positive association between the two variables. Comparing to the current study, scope of this study is limited on the two variables and only involves Gen Y Professionals in three countries as unit of analysis.

Review on literature found only one study discussing the public opinion on APSC. The article Regional Public Opinion towards the Formation of Political Security Community in Southeast Asia, written by Abdullah and 
Benny (2013) based on their study in 2013, analyses and compares awareness, attitude, perception and aspiration for the APSC in Indonesia, Malaysia and Singapore based on their survey in 2010 and found that public lacked awareness, perceived APSC as elitist state-centric agenda, but displayed some positive attitudes and supports for APSC.

Having discusses previous studies, this study is unique because it aims to compare and analyse the opinion towards APSC and AEC. Secondly, this study also compared the opinion in four ASEAN countries. In this sense, this study includes not only two countries that have been involved in previous studies, but also involve public in two other ASEAN important countriesThailand and Vietnam.

\section{MATERIALS AND METHODS}

\section{Variables and Indicators}

The study used three variables measured by ten Likert indicators that underwent a thorough examination in a series of focus group discussions. The first variable - the awareness AEC and APSC - examined the extent of knowledge of AEC and APSC by using two indicators: knowledge on the APSC and knowledge on the AEC. They were adapted from the indicators of the 2009/2010 ASEAN public opinion study conducted by Benny, Tham and Rashila (2015) as well as the study by Abdullah and Benny (2013). Details of questions are exhibited in Appendix 1.

The second variable - perception of APSC - examined the three kinds of perception using six indicators, including: (1) perceived importance of APSC for their country; (2) perceived importance of APSC to the respondent individually; and (3) perceived benefits of APSC on security and peace of the region; (4) perceived importance of AEC for their country; (5) perceived importance of AEC to the respondent individually; and (6) perceived benefits of AEC on the economic development of ASEAN countries. Most indicators were inspired from the 2010 ASEAN public opinion study by Benny, Tham and Ramli (2015) and Abdullah and Benny (2013) and have undergone a thorough examination in a series of focus group discussions. Details of questions are exhibited in the Appendix.

The third variable — support for APSC and AEC — was measured using two indicators, i.e., support for APSC and support for AEC. The indicator was inspired from the 2010 ASEAN public opinion study by Benny, Tham 
and Ramli (2015), and Abdullah and Benny (2013). Details of questions are exhibited in the Appendix.

\section{Data Collection}

Quantitative survey was used as the main method for data collection. A set of structured self-administered questionnaires were used and translated into four national languages - Indonesian, Malay, Thai, and Vietnamese. Questions were pilot tested to 30 respondents in each country to satisfy validity and reliability requirement as well as to ensure their comprehensibility by respondents.

The study selected university students as respondents because of the complexity of issues of economic liberalisation and political security cooperation. Preeceding the survey, focused group discussions with experts and policy-makers at the Universiti Kebangsaan Malaysia suggested that the survey should focus on educated public for this complexity reason because it is a little bit difficult for general public to answer the questions with authority if they don't understand the issues of regional integration. Purposive quota sampling was employed in the surveys in each capital city (Kuala Lumpur, Jakarta, Bangkok, and Hanoi) between June and November 2015. In each city, the study targeted around 350 respondents between 18 and 30 years old.

To collect responses from survey respondents, the study assigned group of enumerators in each city. The enumerators were selected from campus networks in main public and private universities in Malaysia (Universiti Kebangsaan Malaysia in the suburb of Kuala Lumpur), Indonesia (University of Indonesia and Binus University, Jakarta), Thailand (Thammasat University, Bangkok), and Vietnam (Vietnam National University Hanoi). Preceding the survey, focus group discussions was conducted with professors or lecturers in each city to get their knowledge, insights, and opinions regarding the issues under study.

The method of data collection is as follows. Firstly, researcher formed and trained enumerator teams in each city. Enumerator teams directly met the respondents in public spaces on university campuses (such as cafeterias, libraries, or university corridors) and asked them to fill out the self-administered questionnaire. The respondents who were selected in the study should satisfy the working status requirement and purposive quota sampling design, that includes: (1) level of education (undergraduate and postgraduate @ 50 percent); (2) gender (male and female @ 50 percent); and (3) professional education/working background, including 30 percent from business, banking and economics; 30 percent from social science, political sciences and law; 
30 percent from engineering, technology and science 30 percent; and 10 percent from others (including education, literatures, arts).

\section{Data Analysis}

The study uses descriptive and inferential statistics to achieve the aims of study. To achieve the first research objective, data were analysed using univariate analysis statistics such as frequency, percentage, and mean values. To simplify descriptive analysis, the frequency distributions of 6-point scales were regrouped into two response categories - agree and disagree.

Mean values are used to interpret the extent of awareness, perception and support by using this criteria. As the indicators use 6-scale Likert scale, the value between 1 and 3 is considered as negative while it is positive if the mean value is between 4 and 6 . For awareness variable, the interpretation of mean values is as follow: 1 for "strong unawareness"; 2 for "moderate unawareness"; 3 for "weak unawareness"; 4 for "weak awareness"; 5 for "moderate awareness"; and 6 for "strong awareness." For perception variable, the interpretation of mean values is as follow: 1 for "strong negative perception"; 2 for "moderate negative perception"; 3 for "weak negative perception"; 4 for "weak positive perception"; 5 for "moderate positive perception"; and 6 for "strong positive perception." Finally, for support variable, the interpretation of mean values is as follow: 1 for "strong unsupportive"; 2 for "moderate unsupportive"; 3 for "weak unsupportive"; 4 for "weak supportive"; 5 for "moderate supportive"; and 6 for "strong supportive."

In order to find differences between responses in four countries, data in four countries were further analysis to compare means for significant difference. For this purpose, the study employed One-Way Analysis of Variance (Oneway ANOVA) with Post-Hoc Least Square Difference (LSD) Tests. Secondly, to achieve the second objective, the study uses Paired-Samples T-Tests to compare the indicators of awareness, perception and support for APSC with those for AEC.

\section{Methodological Limitation}

The study acknowledges some methodological limitations. Firstly, the measurement of variables that is considered too direct and unsophisticated. The study does not assess awareness, perception and support for APSC and AEC in their specific characteristics, but in their holistic integration because the second purpose of the study is to compare the awareness, perception and support for the two types of ASEAN integration. 
Secondly, the study was conducted in only four out of ten ASEAN members. The study only involves public opinion in Indonesia, Malaysia, Thailand and Vietnam. The selection of the four countries was justified as: (1) they are considered important in ASEAN in terms of territorial size, population, and economy; (2) three countries-Indonesia, Malaysia and Thailand - are among the five ASEAN founders; and (3) Vietnam is included as one of ASEAN newer members. However, given the uniqueness of the other six ASEAN countries not involved in the survey, the study does not pretend to represent them.

Finally, the study used convenience quota, non-random sampling to select the targeted public in the four cities. However, the choice of the targeted public - only those with tertiary education background - was unavoidable because of the requirement of critical thinking among the respondent to answer the questions. Therefore, the findings from the study cannot be generalised to the general public in ASEAN. However, due to large number of respondents involved, the results can be used to understand possible trends among the educated young public on the issues studied.

\section{Respondents Demography}

A number of 1,471 respondents involved in the study consisted of the Gen Y respondents who were attending undergraduate and postgraduate schools in leading public and private universities, since it was logistically impossible (given time and resource constraints) to extend the sample to include the general public in the four countries. The survey involved 387 Indonesians, 374 Malaysians, 350 Thais and 360 Vietnamese. In terms of gender, the respondents were almost balanced between male ( 47 percent) and female (53 percent). In each country the proportion is somewhat different: 49 percent male and 51 percent female in Indonesia and Thailand; 48 percent male and 52 percent female in Malaysia; and 42 percent male and 58 percent female in Vietnam.

The study targeted those between 18 and 30 years old, and divided them into two groups: 18-25 and 26-30. Those between 18 and 25 years old formed the majority of respondents in all countries surveyed ( 74 percent in general: 77 percent Indonesians, 71 percent Malaysians, 79 percent Thais and 67 percent Vietnamese). 
Table 1: Respondent profiles.

\begin{tabular}{|c|c|c|c|c|c|c|c|}
\hline & \multicolumn{5}{|c|}{ Country } \\
\hline & & & Indonesia & Malaysia & Thailand & Vietnam & Overall \\
\hline \multicolumn{3}{|c|}{ Number of respondents } & 387 & 374 & 350 & 360 & 1,471 \\
\hline & & & \multicolumn{5}{|c|}{ Percentage } \\
\hline \multirow{2}{*}{ Gender } & \multicolumn{2}{|l|}{ Male } & 49 & 48 & 49 & 42 & 47 \\
\hline & \multicolumn{2}{|l|}{ Female } & 51 & 52 & 51 & 58 & 53 \\
\hline \multirow{2}{*}{ Age } & \multicolumn{2}{|c|}{$18-25$ years old } & 77 & 71 & 79 & 67 & 74 \\
\hline & \multicolumn{2}{|c|}{ 26-30 years old } & 23 & 29 & 21 & 33 & 26 \\
\hline \multirow{4}{*}{$\begin{array}{l}\text { Current } \\
\text { education } \\
\text { level }\end{array}$} & \multirow{2}{*}{$\begin{array}{l}\text { Under- } \\
\text { graduate }\end{array}$} & Diploma & 0 & 2 & 1 & 0 & 1 \\
\hline & & $\begin{array}{l}\text { Bachelor } \\
\text { degree }\end{array}$ & 52 & 51 & 49 & 67 & 55 \\
\hline & \multirow{2}{*}{$\begin{array}{l}\text { Post- } \\
\text { graduate }\end{array}$} & $\begin{array}{l}\text { Master } \\
\text { degree }\end{array}$ & 48 & 44 & 50 & 33 & 44 \\
\hline & & $\mathrm{PhD}$ & 0 & 3 & 0 & 0 & 1 \\
\hline \multirow{4}{*}{ Area of study } & \multicolumn{2}{|c|}{$\begin{array}{l}\text { Business, banking } \\
\text { and economics }\end{array}$} & 43 & 24 & 31 & 37 & 34 \\
\hline & \multicolumn{2}{|c|}{$\begin{array}{l}\text { Social sciences, } \\
\text { humanities \& law }\end{array}$} & 24 & 34 & 30 & 30 & 29 \\
\hline & \multicolumn{2}{|c|}{$\begin{array}{l}\text { Engineering, } \\
\text { technology and } \\
\text { sciences }\end{array}$} & 26 & 31 & 30 & 28 & 29 \\
\hline & \multicolumn{2}{|c|}{$\begin{array}{l}\text { Others (literature, } \\
\text { education, etc.) }\end{array}$} & 7 & 11 & 9 & 5 & 8 \\
\hline \multirow{4}{*}{$\begin{array}{l}\text { Occupational } \\
\text { background }\end{array}$} & \multicolumn{2}{|c|}{ Public sector } & 14 & 27 & 20 & 24 & 21 \\
\hline & \multicolumn{2}{|c|}{ Private sector } & 32 & 14 & 13 & 21 & 20 \\
\hline & \multicolumn{2}{|c|}{ Self-employed } & 7 & 8 & 17 & 5 & 9 \\
\hline & \multicolumn{2}{|l|}{ Student } & 47 & 51 & 50 & 50 & 49 \\
\hline
\end{tabular}

Due to complicatedness of the questions, the study set higher education as requirement to the respondents. Therefore, based on the current education level, the respondents have undergraduate (56 percent in general: 52 percent Indonesians, 51 percent Malaysians, 50 percent Thais and 67 percent in Vietnam) or postgraduate education (44 percent in general: 48 percent Indonesians, 47 percent Malaysians, 50 percent Thais and 33 percent Vietnamese).

The study has tried its best to differentiate the areas of study background of the respondents in the fieldwork. The results of the areas of study are as follow: 34 percent respondents have either business, banking, and economy education background (43 percent Indonesians, 24 percent Malaysians, 31 percent Thais and 37 percent Vietnamese); 29 percent have either social sciences, humanities (24 percent Indonesians, 34 percent Malaysians, 30 
percent Thais and 30 percent Vietnamese) or law or engineering, technology and sciences (26 percent Indonesians, 31 percent Malaysians, 30 percent Thais and 28 percent Vietnamese); 8 percent have either literature, education, and so on ( 7 percent Indonesians, 11 percent Malaysians, 9 percent Thais and 5 percent Vietnamese). Finally, concerning occupational background, majority (49 percent) of the respondents are students. Among those who work, majority work in public sector ( 21 percent), private sector ( 20 percent). In addition, 9 percent of respondents are self-employed.

\section{RESULTS AND DISCUSSION}

\section{Awareness of ASEAN Regionalism Initiatives}

The study argue that it is important to know whether public are aware of the economic and political regionalism processes that are occurring in ASEAN because awareness may affect public perception and support for the regionalism processes. In general, the awareness of APSC and AEC is still weak in four countries surveyed.

\section{Awareness of APSC}

Majority respondents (in general 54 percent; 66 percent Indonesia; 38 percent Malaysia; 56 percent Thailand; 55 percent Vietnam) stated that they have knowledge of the APSC. The mean value (3.57) shows the extent of awareness for APSC is actually weak as it indicates that in average the public is only "somewhat agree" of having awareness on APSC. Using One Way ANOVA and Post-Hoc LSD tests, the study found that respondents in Indonesia (mean $=3.83$ ) and Vietnam (3.68) seem to have stronger awareness than those in Thailand (3.58) and Malaysia (3.19). The Post-Hoc LSD test also shows the awareness in Malaysia seems very much weaker than the other three countries.

\section{Awareness of AEC}

Majority respondents (in general 66 percent; 77 percent Indonesia; 58 percent Malaysia; 70 percent Thailand; 58 percent Vietnam) stated that they have knowledge of the AEC. The mean value (3.84) shows the extent of awareness for AEC is weak as it indicates that in average the public is only "somewhat agree" of having awareness of AEC. Using One Way ANOVA and Post-Hoc LSD tests, the study found that respondents in Indonesia (mean $=4.05)$ seem to 
have stronger awareness than the other three countries, while the Vietnamese awareness (3.95) is stronger than those in Thailand (3.81) and Malaysia (3.54). The Post-Hoc LSD test also shows the awareness in Malaysia seems very much weaker than the other three countries.

The relatively higher awareness in Indonesia can be explained by the socialisation of the idea in this country. From some series of FGDs conducted in Jakarta in December 2015 to discuss the result of the study, it is indicated that the higher awareness in Indonesia maybe resulted from the interaction between (central and local) government campaigns and the role of civil societies and mass media criticising the lack of preparation strategies from Indonesian government. The role of civil societies and mass media in policy making in Indonesia become significantly stronger after democratic reforms in 1999 after the collapse of authoritarian Soeharto administration one year before. The issue of Indonesian government's lackadaisical moves on preparing the people was heavily criticised and got coverage from the media.

\section{PERCEPTION OF ASEAN REGIONALISM INITIATIVES}

\section{Perception of ASEAN Political Security}

The study argue that it is important to know whether the respondents perceive that ASEAN Community as relevant as well as beneficial because it will determine the level of support among the public for the regional integration. This study includes perceived relevancy and perceived benefits as variable measured from the public. Perceived Relevancy indicates the importance of the ASEAN liberalisation to the respondent individually as well as to their country and its people while perceived benefits identify whether the respondents think ASEAN liberalisation will benefit them. Perceptions of the APSC among the respondents in four countries are as follow.

\section{Perceived relevance of APSC for the respondents individually}

Two-thirds respondents in four countries (66 percent; 77 percent Indonesia; 58 percent Malaysia; 70 percent Thailand; 58 percent Vietnam) stated that APSC is "somewhat important" for them individually. The mean value of 3.87 shows the extent of perceived relevancy is actually slightly weak. ANOVA's Post Hoc LSD tests find that perception is the highest in Vietnam (mean $=4.16)$, followed by Indonesia (3.97) and Thailand (3.82). The perception in Malaysia (3.56) is the lowest among the four countries. 


\section{Perceived relevance of APSC for the country and people}

Three-fourths respondents in four countries ( 75 percent; 75 percent Indonesia; 72 percent Malaysia; 74 percent Thailand; 82 percent Vietnam) stated that APSC is "somewhat important" for their country and its people. The mean value of 4.09 shows the extent of perceived relevancy is actually slightly weak. ANOVA's Post Hoc LSD tests find that perception is significantly highest in Vietnam (mean $=4.41$ ) and lowest in Malaysia (3.86). Perception in Indonesia (4.08) and Thailand (4.04) is significantly lower than Vietnam but higher than in Malaysia.

\section{Perceived benefit of APSC for providing more security and peace to the region}

More than three-fourths respondents in four countries ( 76 percent; 79 percent Indonesia; 72 percent Malaysia; 71 percent Thailand; 84 percent Vietnam) stated that APSC will be beneficial for security and peace of the region. The mean value of 4.15 shows the extent of perceived benefit is actually slightly weak. ANOVA's Post Hoc LSD tests find that perception is significantly highest in Vietnam (mean = 4.61) and lowest in Malaysia (3.92) and Thailand (3.97). Perception in Indonesia (mean $=4.13$ ) is significantly lower than Vietnam but higher than in Thailand and Malaysia.

\section{Perception of ASEAN Economic Community}

Perceptions of the AEC among the respondents in four countries are as follow:

\section{Perceived relevance of AEC for the respondents personally}

Four-fifths of respondents in four countries ( 80 percent; 86 percent Indonesia; 70 percent Malaysia; 81 percent Thailand; 80 percent Vietnam) stated that AEC is "somewhat important" for them personally. The mean value of 4.28 shows the extent of perceived relevancy is actually slightly weak. ANOVA's Post Hoc LSD tests find that perception is the highest in Vietnam (mean = 4.58), and the lowest in Malaysia (3.96). Perception in Indonesia (4.37) is not significantly different with that in Thailand (4.23) - they are significantly lower than that in Vietnam but higher than in Malaysia. 


\section{Perceived relevance of AEC for the country and people}

A very strong majority of respondents (in general 85 percent; 85 percent Indonesia and Malaysia; 81 percent Thailand; 88 percent Vietnam) stated that AEC is "somewhat important" for their country and its people. The mean value of 4.46 shows the extent of perceived relevancy is actually slightly weak. ANOVA's Post Hoc LSD tests find that perception is significantly highest in Vietnam (mean $=4.68)$ and lowest in Indonesia (4.35), Malaysia (4.37) and Thailand (4.45).

\section{Perceived benefit of AEC for bringing economic development of ASEAN countries}

A strong majority of respondents ( 88 percent: 87 percent Indonesia; 91 percent Malaysia; 83 percent Thailand; 91 percent Vietnam) stated that AEC will bring benefits to economic development of ASEAN countries. The mean value of 4.48 shows the extent of perceived benefit is actually in moderate level. ANOVA's Post Hoc LSD tests find that perception is significantly highest in Vietnam (mean $=4.68)$ and lowest in Thailand (4.32). Perception in Indonesia (4.41) and Malaysia (4.52) is significantly lower than Vietnam but higher than in Thailand.

The study found that perceived relevance of APSC as well as the AEC for the country and people in general is higher than the relevance for personal matters. This phenomena may be explainable by the current mechanism of establishing the ASEAN Community that mainly state-centric and elitist. Consequently, the public feel a little bit in distance resulting in the lower perception of APSC relevance to them personally.

\section{SUPPORT FOR ASEAN REGIONALISM INITIATIVES}

\section{Support for the APSC}

The study argues that any regionalism initiatives need to be supported by the public because support is the foundation of any policies. Thus, it is important to know the level of support among the public for the ASEAN Community.

Nearly three-quarters of respondents (in general 74 percent; 84 percent Indonesia; 75 percent Malaysia; 75 percent Thailand; 62 percent Vietnam) stated that they supported the establishment of APSC. The mean value (4.12) shows the extent of support for APSC is rather weak. Using One Way ANOVA 
and its Post-Hoc LSD tests, the study found that the support in Indonesia (mean $=4.33$ ) is the highest compared in the other three countries, while the support in Malaysia (4.01) and Vietnam (3.99) is the lowest. The support in Thailand (4.16) is lower than Indonesia but higher than in Malaysia and Vietnam.

The finding that Indonesia's support for APSC is the highest among the four countries may relate with the history that Indonesia has been the strongest promoter of APSC idea since its conception reflected in the Bali Concord 2003. Rodolfo Severino (2006) discussed in his book that the Indonesian Foreign Minister Hassan Wirayuda promoted the idea of APSC and supported the Philippines' suggestion of ASCC in ASEAN meetings since the end of 2002. Severino (2006) discussed how ideas pertaining to economic integration and liberalization dominated the discussions of ASEAN integration. He asserts that Indonesia strongly advocated the APSC because Indonesia did not want economic discussions, particularly on the AEC, become the sole issue of the 2003 ASEAN Summit. The other reasons for Indonesian active advocacy for the idea is because of Indonesia's security instability in the beginning of 2000s with some terrorist activities destabilising this ASEAN largest country, thus Indonesia concerned about the flow of arms to Indonesian separatist groups from or through neighbouring countries and the lack of coherence of ASEAN's response to global security issues during that period. In addition, Indonesia also has seen an opportunity to advance democratic and human rights agenda in ASEAN in the context of APSC (Benny 2016b).

\section{Support for the AEC}

A strong majority of respondents (in general 87 percent; 90 percent Indonesia; 89 percent Malaysia; 74 percent Thailand; 94 percent Vietnam) stated that they are for the establishment of AEC. The mean value (4.54) shows the extent of support for AEC is actually in moderate level. Using One Way ANOVA and its Post-Hoc LSD tests, the study found that the support in Vietnam (mean $=4.83$ ) is the highest among the four countries, while the support in Thailand (4.26) is the lowest. The support in Indonesia (4.55), not significantly different with that in Malaysia (4.53), were lower than Vietnam but higher than in Thailand.

The study's finding that support for AEC was significantly higher in Vietnam than in the other three countries is explainable by Vietnamese public's good perception toward ASEAN in maintain their economic growth. Tien Dung Nguyen and Mitsuo Ezaki (2005) argue that ASEAN regional economic integration benefits Vietnam's economy in terms of welfare, income- 
distribution, household consumption and income, greater market access, and exports. Analysis on the Vietnam's exports to ASEAN countries shows that the figures increased from USD980.8 million in 1995 to USD18,063.7 million in 2015. Its imports from ASEAN countries also increased from USD2,267.2 million to USD23,827.4 million (ASEAN Secretariat 2006).

\section{COMPARING AWARENESS, PERCEPTION, SUPPORT FOR APSC AND AEC}

In achieving the second research objective, Paired-t-Test is used to compare the awareness, perception as well as the support for APSC with that of AEC. The results of comparison tests are shown in Table 2.

Table 2: Comparison of Awareness, Perception and Support for APSC and AEC.

\begin{tabular}{|c|c|c|c|}
\hline $\begin{array}{l}\text { Variable for } \\
\text { comparison }\end{array}$ & APSC & $\mathrm{AEC}$ & Finding and Analysis \\
\hline $\begin{array}{l}\text { Awareness of } \\
\text { APSC and AEC }\end{array}$ & $\begin{array}{l}\text { Mean }=3.77 \\
\text { Std. dev. }=1.19\end{array}$ & $\begin{array}{l}\text { Mean }=3.84 \\
\text { Std. dev. }=1.19\end{array}$ & $\begin{array}{l}\text { Finding: } t=-2.193 ; \mathrm{df}=1450 ; \text { Sig } \\
\text { (2-tailed) }=0.028 \\
\text { Analysis: Awareness of AEC is } \\
\text { significantly higher than that of APSC }\end{array}$ \\
\hline $\begin{array}{l}\text { Perceived } \\
\text { relevance for } \\
\text { the respondents } \\
\text { personally }\end{array}$ & $\begin{array}{l}\text { Mean }=3.87 \\
\text { Std. dev. }=1.17\end{array}$ & $\begin{array}{l}\text { Mean }=4.27 \\
\text { Std. dev. }=1.08\end{array}$ & $\begin{array}{l}\text { Finding: } t=-12.514 ; \mathrm{df}=1449 \text {; } \\
\text { Sig }(2 \text {-tailed })=0.000 \\
\text { Analysis: Perceived important of } \\
\text { AEC is significantly higher than that } \\
\text { of APSC }\end{array}$ \\
\hline $\begin{array}{l}\text { Perceived } \\
\text { relevance for the } \\
\text { country/people }\end{array}$ & $\begin{array}{l}\text { Mean }=4.08 \\
\text { Std. dev. }=1.07\end{array}$ & $\begin{array}{l}\text { Mean }=4.45 \\
\text { Std. dev. }=1.01\end{array}$ & $\begin{array}{l}\text { Finding: } t=-11.740 ; \mathrm{df}=1424 ; \\
\text { Sig (2-tailed) }=0.000 \\
\text { Analysis: Perceived important of } \\
\text { AEC is significantly higher than that } \\
\text { of APSC }\end{array}$ \\
\hline $\begin{array}{l}\text { Perceived benefits } \\
\text { from integration / } \\
\text { cooperation }\end{array}$ & $\begin{array}{l}\text { Mean }=4.15 \\
\text { Std. dev. }=1.11\end{array}$ & $\begin{array}{l}\text { Mean }=4.48 \\
\text { Std. dev. }=0.95\end{array}$ & $\begin{array}{l}\text { Finding: } t=-10.519 ; \mathrm{df}=1450 ; \\
\text { Sig }(2 \text {-tailed })=0.000 \\
\text { Analysis: Perceived benefit of AEC is } \\
\text { significantly higher than that of APSC }\end{array}$ \\
\hline $\begin{array}{l}\text { Support for } \\
\text { integration }\end{array}$ & $\begin{array}{l}\text { Support for } \\
\text { APSC: } \\
\text { Mean }=4.12 \\
\text { Std. dev. }=1.14\end{array}$ & $\begin{array}{l}\text { Support for } \\
\text { AEC: } \\
\text { Mean }=4.54 \\
\text { Std. dev. }=1.01\end{array}$ & $\begin{array}{l}\text { Finding: } t=-12.813 ; \mathrm{df}=1446 \text {; } \\
\text { Sig (2-tailed) }=0.000 \\
\text { Analysis: Support for AEC is } \\
\text { significantly higher than that for } \\
\text { APSC }\end{array}$ \\
\hline
\end{tabular}




\section{Comparing Awareness of APSC and AEC}

The Paired-t-Test shows that the awareness of AEC (mean $=3.84)$ in four countries is significantly higher than that of the APSC (mean $=3.77$ ). This finding is plausible because government in the four ASEAN countries focuses more on economic benefits from the integration on their messages when they did campaign on the regionalism initiatives to their public.

\section{Comparing Perception of APSC and AEC}

The Paired-t-Test shows that the perceptions of AEC are significantly higher than that of APSC. The statistics show that, for personal matters, the perception of relevance of AEC (mean $=4.27)$ is higher than that of APSC $($ mean $=3.87)$. In addition, the respondents also perceived relevance of the AEC (mean $=$ 4.45 ) to their country and people is higher than that of the APSC (mean = 4.08). Finally, the study also discovers that the respondents' perception of AEC's benefit (mean $=4.48)$ is higher than that of APSC $($ mean $=4.15)$.

The finding that AEC is considered as more relevant and beneficial for them personally and for their country, people and the region is reasonable because almost all the countries in ASEAN have followed the model of developmental state that focuses more on economic development than political matters, so mainstream media discuss mostly about economic development. As the results, public are more interested in economic relevance and benefits of the ASEAN Community.

\section{Comparing the Support for APSC and AEC}

The Paired- $t$-Test shows that the support for AEC (mean $=4.54$ in four countries is significantly higher than that of the APSC (mean = 4.12). The proximity of economic issues to the respondents may play a role in the state of higher support for AEC in comparison to APSC. In this case, political security integration is considered as a more distant issue to the respondents than economic integration, resulting in the higher support for AEC than APSC.

A study by Benny, Moorthy, Daud and Othman (2015a) may explain why the support for AEC tends to be higher than APSC. Their study was conducted using 2010 public opinion data on the effect of elitist regionalism process in ASEAN found the association between elitist, state-centric regional integration process in ASEAN and support for its formation. Thus, the study argues that, because policy makers in ASEAN tend to consider the issue of political security tends as state-domains, the public was less involved in 
political security decision making than it is on economic regionalism. This perception of "distantness" from the public thus may play the role in higher support for AEC than it is for APSC.

\section{CONCLUSION}

This study analysed the data taken by surveying 1,471 Gen Y respondents in four ASEAN countries. The study found that the extent of awareness of both APSC and AEC is still weak resulting in weak extent of perceived relevancy and benefits as well as weak support for APSC and moderate-level support for AEC. Given that previous studies showed the effect of awareness on perception and support, the study urges national government to formulate and implement the strategy to bring ASEAN economic and political security integration and cooperation closer to the public.

Finally, the study found that awareness, perception and support for economic integration in ASEAN were stronger than that of political security cooperation. The study indicates that the distance of political security issues to the public as well as the state-centric APSC process that resulted in the distance of political security cooperation to the public. However, successful political security cooperation and economic integration requires active participation not only from the elites but also from the public. Thus, the study reiterates the requirement to bring ASEAN integration to, not only "people-centred ASEAN" that is actually very rhetorical, but it should be "people-involved ASEAN integration."

\section{ACKNOWLEDGEMENTS}

The research is partially funded by the Ministry of Higher Education Malaysia's Research University Grant (GUP) UKM-GUP-TKS-07-10-96 and the Thai Embassy in Kuala Lumpur (UKM-Thai Window Project). The authors would like to express their gratitude to the funding agencies. 


\section{NOTES}

* Guido Benny is a senior lecturer at the School of Liberal Arts, Taylor's University, Malaysia. His research interests include regionalism, ASEAN, public opinions and participation in regional integration, and security and economic regionalism and cooperation in Southeast and Northeast Asia. He has written some chapters in books and many articles in internationally refereed journals. Some of his publications include Attitude, Challenges and Aspiration for the ASEAN Community 2015 and Beyond: Comparative Public Opinion in Malaysia and Thailand, 2016, The Social Sciences 11 (22); Contestation of Regional and National Identities: Effect on Support for the Asean Community, 2016, Tamkang Journal of International Affairs 20 (2); Perceived Elitist and State-Centric Regional Integration Process: Impact on Public Opinions for the Formation of ASEAN Community, 2015, Mediterranean Journal of Social Sciences 6 (2); Public Opinion on the Formation of the Asean Economic Community: An Exploratory Study in Three ASEAN Countries, 2015, International Journal of Asia Pacific Studies 11 (1); and Is the ASEAN Economic Community Relevant To Gen Y Professionals? A Comparative Study on Attitudes and Participation of Young Professionals in Malaysia, Indonesia, and Vietnam on ASEAN Economic, 2015, The Asian Journal for Public Opinion Research 3 (1). He can be contacted at guidobenny@gmail.com.

** Sity Daud is Associate Professor of Political Science at the History, Politics and Security Centre, Universiti Kebangsaan Malaysia. Her research interest is on East Asian political economy, nontraditional security issues, and good governance. She has published on development, politics, and human security in Asia Pacific. She is also the Deputy President of the Malaysian Social Science Association (PSSM). She can be contacted at sitydaud@ukm.edu.my.

*** Ravichandran Moorthy is Associate Professor and Head of the International Relations Cluster in the History, Politics and Security Research Centre, Universiti Kebangsaan Malaysia. He teaches international relations, ASEAN and Asia Pacific security at the university. Prior to his University position, he was a senior officer in the cadre of Diplomatic and Administrative Service, in the Malaysian civil service. He served in several positions at the Institute of Diplomacy and Foreign Relations (IDFR), Malaysia, the National Institute of Public Administration (INTAN), and as Head of Multilateral Division, Ministry of Science, Technology and Innovation, Malaysia. He researches on ASEAN, Indian Ocean geopolitics and environmental security. He has lead research projects on Malaysia-Indonesia relations, China's energy security and Mekong River geopolitics. He has been active in several UNESCO working groups in the Ethics and Climate Change in Asia and the Pacific (ECCAP) project, and was appointed as regional expert for consultation on the revision to the Universal Declaration of Human Rights. He was awarded the status of 'Professor of Honour' by the Institute of East China Sea Rim and Borderland, Zhejiang Normal University, China in 2017. In 2014, he was appointed Visiting Professor to the Southeast Asian Studies Programme at Puget Sound University, Tacoma, United States. He was also appointed consultant to the Timor Leste's Diplomatic Institute, in the development of diplomatic curriculum, where he is also an adjunct professor. He is an adjunct professor 
at the American University of Sovereign Nations, in the United States. He is often consulted by security agencies, embassies and the media on regional geopolitics. His publications have appeared in high impact journals like Asian Survey, International Relations of the Asia Pacific (IRAP) and Tamkang Journal of International Relations. He can be contacted at drravi5774@gmail.com ordrravi@ukm.edu.my.

\section{REFERENCES}

Abdullah, K. and Benny, G. 2013. Regional public opinion towards the formation of political security community in Southeast Asia. Asian Journal of Scientific Research 6 (4): 650-665, https://doi.org/10.3923/ajsr.2013.650.665.

Abidin, Z. A., Loh, G. M. and Aziz, N. I. A. 2012. Achieving the AEC 2012: Challenges for the Malaysian private sector. In Achieving the ASEAN economic community 2015, ed. Das, S. B., 224-248. Singapore: Institute of Southeast Asian Studies.

Acharya, A. 2003. Democratisation and the prospects for participatory regionalism in Southeast Asia. Third World Quarterly 24 (2): 375-390, https://doi.org/10.1080/01 43659032000074646.

ASEAN Secretariat. 2016. External trade statistics as 10 June 2016. http://asean.org/?static post=external-trade-statistics-3 (accessed 4 August 2016).

Asian Development Bank Institute (ADBI). 2012. ASEAN 2030: Towards a borderless economic community, draft highlights. Tokyo: ADBI.

Benny, G. 2014. Kesan sentimen nasionalisme terhadap komitmen mengutamakan komuniti ekonomi ASEAN: Analisis empirikal daripada survei di Indonesia, Malaysia dan Singapura [Effect of nationalism towards commitment to prioritize ASEAN Economic Community: Empirical analysis from surveys in Indonesia, Malaysia and Singapore]. JEBAT: Malaysian Journal of History, Politics and Strategy 41 (2): 23-49.

2015. Is the ASEAN economic community relevant to Gen Y professionals? A comparative study on attitudes and participation of young professionals in Malaysia, Indonesia, and Vietnam on ASEAN economic integration. Asian Journal for Public Opinion Research 3 (1): 40-62, https://doi.org/10.15206/ajpor.2015.3.1.40. . 2016a. Contestation of regional and national identities: Effect on support for the ASEAN community. Tamkang Journal of International Affairs XX (II): 49-88. .2016b. Attitude, challenges and aspiration for the ASEAN community 2015 and beyond: Comparative public opinion in Malaysia and Thailand. The Social Sciences 11 (22): 5488-5495.

Benny, G. and Abdullah, K. 2011. Indonesian perceptions and attitudes toward the ASEAN community. Journal of Current Southeast Asian Affairs 30 (1): 39-67.

Benny, G., Moorthy, R., Daud, S. and Othman, Z. 2015a. Perceived elitist and state-centric regional integration process: Impact on public opinions for the formation of ASEAN community. Mediterranean Journal of Social Sciences 6 (2): 203-212, https://doi. org/10.5901/mjss.2015.v6n2s1p203.

.2015b. Impact of nationalist sentiments and commitment for prioritising the ASEAN economic community: Empirical analysis from survey in Indonesia, Malaysia and Singapore. Mediterranean Journal of Social Sciences 6 (1S1): 188-199. 
Benny, G., Ramli, R. and Tham, S. Y. 2014. Nationalist sentiments and perceived threats: Public opinion in Indonesia, Malaysia, and Singapore and implications to the establishment of ASEAN community. Tamkang Journal of International Affairs XVIII (I): 59-108.

Benny, G., Tham, S. Y. and Ramli, R. 2015. Public opinion on the formation of the ASEAN economic community: An exploratory study in three ASEAN countries. International Journal of Asia Pacific Studies 11 (1): 85-114.

Caballero-Anthony, M. 2008. The ASEAN Charter. Southeast Asian Affairs. Singapore: Institute of Southeast Asian Studies.

Chavez, J. J. 2007. Global social policy forum: Civil society challenging ASEAN. Global Social Policy 7 (3): 260-262, https://doi.org/10.1177/14680181070070030204.

Collins, A. 2008. A people-oriented ASEAN: A door ajar or closed for civil society organisations? Contemporary Southeast Asia 30 (2): 313-321, https://doi. org/10.1355/CS30-2G.

Economic Research Institute for ASEAN and East Asia (ERIA). 2012. Mid-term review of the implementation of AEC Blueprint: Executive summary. Jakarta: ERIA.

Guerrero, R. B. 2008. Regional integration: The ASEAN vision in 2020. IFC Bulletin 32: $52-58$.

Hew, D. 2007. Brick by brick: The building of an ASEAN Economic Community. Singapore: Institute of Southeast Asian Studies.

Hewstone, M. 1986. Understanding attitudes to the European community a sociopsychological study in four member states. Cambridge: Cambridge University Press.

Knoema. 2016. Thailand - Contribution of travel and tourism to GDP as a share of GDP. https://knoema.com/atlas/Thailand/topics/Tourism/Travel-and-TourismTotal-Contribution-to-GDP/Total-Contribution-to-GDP-percent-share (accessed 3 August 2016).

Lindberg, L. and Scheingold, S. 1970. Europe's would-be polity. Englewood Cliffs, New Jersey: Prentice Hall.

Moorthy, R. and Benny, G. 2012a. Attitude towards community building in Association of Southeast Asian Nations: A public opinion survey. American Journal of Applied Science 9: 557-562, https://doi.org/10.3844/ajassp.2012.557.562. . 2012b. Is "ASEAN Community" achievable? A public perception analysis in Indonesia, Malaysia and Singapore on the perceived obstacles for a regional community. Asian Survey 52 (6): 1043-1066, https://doi.org/10.1525/ as.2012.52.6.1043.

2013. Does public opinion count? Knowledge and support for an ASEAN community in Indonesia, Malaysia, and Singapore. International Relations of the Asia Pacific 13: 399-423, https://doi.org/10.1093/irap/lct008.

Mugijayani, W. and Kartika, P. 2012. Perspective of the Indonesian Business Sector on the Regional Integration Process. In Achieving the ASEAN Economic Community 2015, ed. Das, S. B., 196-223. Singapore: Institute of Southeast Asian Studies.

Nguyen, T. D. and Ezaki, M. 2005. Regional economic integration and its impacts on growth, poverty, and income distribution: The case of Vietnam. Review of Urban and Regional Development Studies 17 (3): 197-215, https://doi.org/10.1111/j.1467940X.2005.00104.x. 
Ortuoste, M. C. 2008. From an elite- to a people-centred regionalism; from an illiberal peace to a human rights regime? The prospect of human rights in Southeast Asia. Paper presented at the annual meeting of the ISA's 49th Annual Convention, Bridging Multiple Divides, San Francisco, CA. http://www.allacademic.com/meta/2538 index.html.

Severino, R. C. 2006. Southeast Asia in search of an ASEAN community. Singapore: Institute of Southeast Asian Studies.

Siraprapasiri, P. and Thalang, C. N. 2016. Towards the ASEAN community: Assessing the knowledge, attitudes, and aspirations of Thai university students. Journal of Current Southeast Asian Affairs 35 (2): 1-35.

Tan, L. H. 2004. Will ASEAN economic integration progress beyond a free trade area? International and Comparative Law Quarterly 53:935-967, https://doi.org/10.1093/ iclq/53.4.935.

Thompson, E.C., Thianthai, C. and Thuzar, M. 2016. Do young people know ASEAN? Update of a ten-nation survey. Singapore: ISEAS Publishing. 


\section{APPENDIX}

\section{Survey Question Wording}

\begin{tabular}{|c|c|c|}
\hline Variables & Questionnaire & Coding \\
\hline \multirow{2}{*}{$\begin{array}{l}\text { Awareness of } \\
\text { APSC and AEC }\end{array}$} & $\begin{array}{l}\text { I have sufficient knowledge } \\
\text { about the ASEAN Political } \\
\text { Security Community. }\end{array}$ & $\begin{array}{l}\text { Completely disagree }=1 ; \text { Disagree } \\
=2 ; \text { Somewhat disagree }=3 ; \\
\text { Somewhat agree }=4 ; \text { Agree }=5 ; \\
\text { Completely agree }=6\end{array}$ \\
\hline & $\begin{array}{l}\text { I have sufficient knowledge } \\
\text { about the ASEAN Economic } \\
\text { Community. }\end{array}$ & $\begin{array}{l}\text { Completely disagree }=1 ; \text { Disagree } \\
=2 ; \text { Somewhat disagree }=3 ; \\
\text { Somewhat agree }=4 ; \text { Agree }=5 ; \\
\text { Completely agree }=6\end{array}$ \\
\hline \multirow{6}{*}{$\begin{array}{l}\text { Perception of } \\
\text { APSC and AEC }\end{array}$} & $\begin{array}{l}\text { The APSC is important for my } \\
\text { country and its people. }\end{array}$ & $\begin{array}{l}\text { Completely disagree }=1 ; \text { Disagree } \\
=2 ; \text { Somewhat disagree }=3 ; \\
\text { Somewhat agree }=4 ; \text { Agree }=5 ; \\
\text { Completely agree }=6\end{array}$ \\
\hline & The APSC is important for me. & $\begin{array}{l}\text { Completely disagree }=1 ; \text { Disagree } \\
=2 ; \text { Somewhat disagree }=3 ; \\
\text { Somewhat agree }=4 ; \text { Agree }=5 ; \\
\text { Completely agree }=6\end{array}$ \\
\hline & $\begin{array}{l}\text { The APSC will provide more } \\
\text { security and peace to Southeast } \\
\text { Asia. }\end{array}$ & $\begin{array}{l}\text { Completely disagree }=1 ; \text { Disagree } \\
=2 ; \text { Somewhat disagree }=3 ; \\
\text { Somewhat agree }=4 ; \text { Agree }=5 ; \\
\text { Completely agree }=6\end{array}$ \\
\hline & $\begin{array}{l}\text { The APSC is important for my } \\
\text { country and its people. }\end{array}$ & $\begin{array}{l}\text { Completely disagree }=1 ; \text { Disagree } \\
=2 ; \text { Somewhat disagree }=3 ; \\
\text { Somewhat agree }=4 ; \text { Agree }=5 ; \\
\text { Completely agree }=6\end{array}$ \\
\hline & The APSC is important for me. & $\begin{array}{l}\text { Completely disagree }=1 ; \text { Disagree } \\
=2 ; \text { Somewhat disagree }=3 ; \\
\text { Somewhat agree }=4 ; \text { Agree }=5 ; \\
\text { Completely agree }=6\end{array}$ \\
\hline & $\begin{array}{l}\text { AEC is a positive development } \\
\text { for the economies of ASEAN } \\
\text { countries. }\end{array}$ & $\begin{array}{l}\text { Completely disagree }=1 ; \text { Disagree } \\
=2 ; \text { Somewhat disagree }=3 ; \\
\text { Somewhat agree }=4 ; \text { Agree }=5 ; \\
\text { Completely agree }=6\end{array}$ \\
\hline \multirow{2}{*}{$\begin{array}{l}\text { Support for APSC } \\
\text { and AEC }\end{array}$} & $\begin{array}{l}\text { I am for the establishment of } \\
\text { ASEAN Political Security } \\
\text { Community. }\end{array}$ & $\begin{array}{l}\text { Completely disagree }=1 ; \text { Disagree } \\
=2 ; \text { Somewhat disagree }=3 ; \\
\text { Somewhat agree }=4 ; \text { Agree }=5 ; \\
\text { Completely agree }=6\end{array}$ \\
\hline & $\begin{array}{l}\text { I am for the establishment of } \\
\text { ASEAN Economic Community. }\end{array}$ & $\begin{array}{l}\text { Completely disagree }=1 ; \text { Disagree } \\
=2 \text {; Somewhat disagree }=3 ; \\
\text { Somewhat agree }=4 ; \text { Agree }=5 ; \\
\text { Completely agree }=6\end{array}$ \\
\hline
\end{tabular}

